\title{
A Comparison of Drug Regimens and Analysis of Effective Factors for Blood Transfusion and Intervention in Spontaneous Rectus Sheath Hematomas
}

\section{Spontan Rektus Kılıf Hematomları: İlaç Rejimlerinin Karșılaștırılması ve Kan Transfüzyonu ve Müdahalesi için Etkili Faktörlerin Analizi}

\author{
(D) Ahmet Sürek1, (1) Mehmet Abdussamet Bozkurt2, (1) Burak Altunpak1 (1)Turgut Dönmez1, (D) Eyüp Gemici1, \\ (1) Sina Ferahman11, (1) Hüsnü Aydın1, (1) Ali Kocataș², (1) Mehmet Karabulut1 \\ IUniversity of Health Sciences Turkey, Bakırköy Dr. Sadi Konuk Training and Research Hospital, Clinic of General Surgery, İstanbul, Turkey \\ 2University of Health Sciences Turkey, İstanbul Kanuni Sultan Süleyman Training and Research Hospital, Clinic of General Surgery, İstanbul, Turkey
}

\begin{abstract}
Objective: Rectus sheath hematomas (RSH) are mostly observed in older patients with a high number of comorbidities. The use of anticoagulants is the most common risk factor for the disease. Our study aimed to determine the effect of the drug regimens and analyze the risk factors for blood transfusion and intervention in cases of RSH.

Method: The records of 46 patients who had been treated for RSH between January 2015 and March 2020 were analyzed retrospectively. The demographic data, drug usage, tomography findings, clinical courses, and morbidity and mortality rates of the patients were recorded. The findings were compared according to the drug regimens, and the risk factors for blood transfusion and intervention were determined.

Results: The mean erythrocyte transfusion (3.61 U), number of patients who underwent erythrocyte transfusion (77\%), mean hematoma size (10.07 cm), and length of hospital stay (7.53 days) were higher in Group l (only using acetylsalicylic acid) patients ( $p=0.002, p=0.011, p=0.016$, and $p=0.004$, respectively). The common risk factors for blood transfusion and intervention, however, were low hemoglobin levels, contrast extravasation and type-3 hematoma on computed tomography (CT), and long hospital stay.

Conclusion: RSH are usually treated conservatively. Blood transfusion, vascular embolization, and/or surgical treatment may be required. Only acetylsalicylic acid use, low hemoglobin levels, long hospital stay, and contrast extravasation, and type 3 hematoma on CT were associated with more blood transfusion and intervention.

Keywords: Rectus sheath, hematoma, conservatively, blood transfusion, vascular embolization

\section{ÖZ}

Amaç: Rektus kılıfı hematomları (RKH) sıklıkla komorbiditesi yüksek yașı hastalarda görülmektedir. Antikoagülan kullanımı, hastalık için en yaygın risk faktörüdür. Bu çalıșma, rektus kılıf hematomunda ilaç rejimlerinin etkisini belirlemeyi ve kan transfüzyonu ve müdahale için risk faktörlerini analiz etmeyi amaçlamaktadır.
\end{abstract}

Cite as: Sürek A, Bozkurt MA, Altunpak B, Dönmez T, Gemici E, Ferahman S, Aydın H, Kocataș A, Karabulut M. A Comparison of Drug Regimens and Analysis of Effective Factors for Blood Transfusion and Intervention in Spontaneous Rectus Sheath Hematomas. IKSSTD 2021;13(3):213-21

\footnotetext{
${ }^{\odot}$ Copyright 2021 by the İstanbul Kanuni Sultan Süleyman Training and Research Hospital / Medical Journal of Istanbul Kanuni Sultan Suleyman published by Galenos Publishing House.
}

๑Telif Hakkı 2021 İstanbul Kanuni Sultan Süleyman Eğitim ve Araștırma Hastanesi / Istanbul Kanuni Sultan Süleyman Tıp Dergisi, Galenos Yayınevi tarafından basılmıștr. 
Yöntem: Ocak 2015 ile Mart 2020 arasında rektus kılıf hematomu nedeniyle tedavi edilen 46 hastanın dosyası geriye dönük olarak incelendi. Hastaların demografik verileri, ilaç kullanımı, bilgisayarlı tomografi (BT) bulguları, klinik seyirleri, morbidite ve mortalite oranları kaydedildi. Veriler hastaların kullandıkları ilaç rejimleri arasında karşılaştırıldı ve kan transfüzyonu ve müdahale için risk faktörleri belirlendi.

Bulgular: Ortalama eritrosit transfüzyonu (3,61 U), eritrosit transfüzyonu yapılan hasta sayısı (\%77), ortalama hematom boyutu $(10,07 \mathrm{~cm})$ ve hastanede kalıș süresi (7,53 gün) Grup l'de daha yüksekti (sırasılla; $p=0,002, p=0,011, p=0,016, p=0,004$ ). Kan transfüzyonu ve cerrahi veya girișimsel embolizasyon için etkili olan ortak risk faktörleri, düșük hemoglobin seviyeleri, BT anjiyografide kontrast ekstravazasyonu ve tip 3 hematom ve uzun hastanede kalıșı olarak bulunmuștur.

Sonuç: Rektus kılıfı hematomları genellikle konservatif olarak tedavi edilir. Kan transfüzyonu, vasküler embolizasyon ve/veya cerrahi tedavi gerekebilir. Sadece asetilsalisilik asit kullanımı, düșük hemoglobin seviyeleri, uzun hastanede kalıș, BT'de kontrast ekstravazasyon ve tip 3 hematom daha fazla kan transfüzyonu ve müdahalesi ile ilişkilendirildi.

Anahtar kelimeler: Rektus kılıf hematomu, konservatif tedavi, kan transfüzyonu, vasküler embolizasyon

\section{INTRODUCTION}

Rectus sheath hematoma (RSH) is usually caused by damage to the superior and inferior epigastric arteries and their branches or directly to the rectus muscle ${ }^{(1)}$. Diagnosis of RSH may be difficult because patients mostly present with abdominal pain or an abdominal mass that may mimic many other conditions ${ }^{(2,3)}$. The disease is usually characterized by a benign course, but more serious problems including mortality have been reported in literature ${ }^{(3)}$. Oral anticoagulants are the most common risk factors associated with RSH. Other risk factors include antiplatelet, drugs pregnancy, hypertension, previous abdominal surgery, and hematological diseases ${ }^{(4,5)}$. The most common trigger factor is acute paroxysmal cough ${ }^{(1,4)}$. RSH is usually diagnosed by a good physical examination and abdominal USG and/or abdominal computed tomography (CT) imaging methods ${ }^{(6)}$. Abdominal CT is not only useful in the exclusion of other intra-abdominal pathologies but is also considered as a gold standard for the diagnosis of RSH with $100 \%$ specificity and sensitivity. RSH is generally managed conservatively. If the bleeding cannot be controlled, vascular embolization or surgical intervention may be required ${ }^{(6,7)}$.

Although the biggest risk factor for RSH has been stated as anticoagulant use, it may also develop by the use of antiplatelet drugs, such as acetylsalicylic acid (ASA) and clopidogrel, or in patients who do not use any drugs $(1,4,8)$. There are no studies in the relevant literature comparing the results of RSH cases caused by these drugs and the mortality and morbidity rates according to the drug types.

The present study aimed to examine the etiology of RSH, compare RSH cases according to the types of drugs used by the patients, and identify the risk factors in patients requiring interventions like blood transfusion and vascular embolization and/or surgery.

\section{METHOD}

The records of patients treated for RSH between January 2015 and March 2020 were reviewed retrospectively. Patients $>18$ years of age, patients with hematoma that developed due to the use of blood thinners, and patients with a hematoma that did not have an etiological cause or that developed due to strain of the rectus muscle caused by heavy load lifting, sports, and straining were included in the study. Patients $<18$ years of age, patients exposed to penetrating or blunt trauma, and patients with RSH that developed after a medical intervention were excluded from the study. A total of 46 patients were included in the study.

The patients included in the study were divided into four groups. Patients who developed RSH due to the use of only ASA were named as Group 1, patients who developed hematoma due to the use of anticoagulants only as Group 2, patients with anticoagulant + clopidogrel use as Group 3, and patients without a history of drug use as Group 4. Patients' information, such as age, gender, body mass index (BMI), Charlson comorbidity indexes (CCl), laboratory values, tomography results, hematoma sizes, blood transfusion needs; intervention requirements, such as vascular embolization or surgery; length of hospital stay; and morbidity and mortality rates were recorded. In the tomography results, the size of the hematomas, whether there was extravasation, and the type of RSH were evaluated. Hematomas were divided into three types according to tomography findings. In type 1 , the hematoma was unilateral and limited to the rectus muscle. In type 2 , it could be unilateral or bilateral and could cause bleeding between the rectus muscle and transverse fascia. In type 3, the hematoma spread over the transverse fascia, peritoneum, and perivesical area ${ }^{(7)}$. The results were compared between the four groups. 
To investigate the factors that affect blood transfusion and intervention needs, patients were divided into two groups as, those who were and could not be transfused and those who were and were not intervened. The results obtained were also compared between these groups, and the risk factors that increased the need for blood transfusion and intervention were determined.

\section{Statistical Analysis}

The Statistical Package for the Social Sciences (SPSS) 24.0 software was used for statistical analysis. Differences between the groups were tested using Pearson's chi-square test or Fisher's exact test for categorical variables, and oneway analysis of variance (ANOVA) and Kruskal-Wallis for continuous variables. The Pearson's chi-square, likelihood, Fisher's exact, and Kruskal-Wallis tests were used in the comparison between groups separated by drug use. The Pearson's chi-square, likelihood, Fisher's exact, and oneway ANOVA tests were used in the comparison between groups created to investigate the factors that affect blood transfusion and intervention needs. The results were considered statistically significant at $p<0.05$ and $p<0.01$.

\section{RESULTS}

\section{General Findings}

The study included a total of 46 patients. Of the patients, 34 (74\%) were female and 12 (16\%) were male. The average age was 65.17 years, and the average BMI was 26.92. There was at least one comorbid disease in $40(87 \%)$ patients, and the mean $\mathrm{CCl}$ was 4.47 . While $33(71.73 \%)$ of the patients had a history of drug use, 13 (28.2\%) were not using any medication. Of the patients using drugs, 13 (28.2\%) used only ASA, 11 (23.91\%) used only anticoagulants, and 9 (19.5\%) used anticoagulants and clopidogrel. Among patients who did not use any medication, two had anamnesis because of sports, three because of heavy lifting, one because of breast cancer, and one because of a hematological disease. No etiological cause was found in six patients. While $36(78 \%)$ patients presented with complaints of abdominal pain, 28 $(60 \%)$ patients presented with a mass in the rectus muscle and 9 (19.5\%) patients with complaints of ecchymosis. RSH was located on the right side in $22(47.8 \%)$ patients, on the left side in $20(43.47 \%)$ patients, and bilaterally in four (8.69\%) patients. The mean hematoma size on abdominal tomography was $8.30 \mathrm{~cm}$. Contrast extravasation was detected in nine (19.5\%) patients. Of these extravasations, six were caused by damage to the inferior epigastric artery, two to the superficial circumflex iliac artery, and one to the superior epigastric artery. While 15 patients had type 1 RSH, 21 patients had Type 2, and 10 patients had type 3 RSH. Red blood cell (RBC) transfusion was performed in 21 patients, vascular embolization in 8 patients, and surgery in 2 patients. Vascular embolization had previously been applied to one of the patients who had undergone surgery. A total of 37 (80.43\%) patients were successfully treated conservatively without the need for any intervention. The average length of hospital stay was 5.21 days. A total of six patients developed morbidity due to the following reasons: disseminated intravascular coagulation (DIC) in one patient, cardiopulmonary complication in one patient, and development of an abscess in four patients at the location of the hematoma. Mortality developed in two patients with DIC and cardiopulmonary complications (Table 1).

\section{Etiology and Comparison of the Types of Drugs that Cause RSH}

The patients were divided into four groups according to their drug use and the type of drug used. Group $1(n=13)$ comprised patients who used only ASA, Group $2(n=11)$ of those who used anticoagulants, Group $3(n=9)$ of those who used anticoagulants and clopidogrel, and Group 4 (n $=13$ ) of those who did not use drugs. Two of the patients using anticoagulants used low-molecular weight heparin, whereas the others used warfarin group drugs. The mean age and number of comorbid diseases of Group 4 were significantly lower compared to those in the other groups ( $p=0.002$ and $p=0.001$, respectively). The groups were similar in terms of gender and BMI. The mean hemoglobin values were significantly higher in Group 4 ( $p=0.003$ ). The mean INR values were significantly higher in groups 2 and $3(p=0.001)$. The mean platelet values were similar. The mean erythrocyte replacement ( 3.61 units), number of people who underwent erythrocyte replacement (10), mean hematoma size $(10.07 \mathrm{~cm})$, and length of hospital stay $(7.53$ days) were significantly higher in Group 1 patients $(p=0.002$, $p=0.011, p=0.016$, and $p=0.004$, respectively) than the other groups. The erythrocyte suspension and fresh frozen plasma (FFP) replacement were significantly less observed in Group 4 compared to the other groups ( $p=0.011$ and $p=$ 0.001 , respectively). Other parameters were similar among the groups (Table 2).

\section{Factors Affecting Blood Transfusion}

RBC erythrocyte suspension transfusion was performed in 21 (45.65\%) patients. Older patients and those with high $\mathrm{CCl}$ had a significantly higher need for blood transfusion 
( $p=0.005$ and $p=0.001$, respectively). The need for more erythrocyte suspension transfusion in patients using only ASA was statistically significant $(p=0.002)$. Other statistically significant factors that increased the risk of

Table 1. General findings and outcomes of patients with spontaneous rectus sheath hematoma

\begin{tabular}{|c|c|}
\hline Mean age (SD) & $65.17(16.81)$ \\
\hline Gender & \\
\hline Male & $12(26 \%)$ \\
\hline Female & $34(74 \%)$ \\
\hline Mean BMI $\left(\mathrm{kg} / \mathrm{m}^{2}\right)(\mathrm{SD})$ & $26.92(3.22)$ \\
\hline Mean CCI (SD) & $4.47(2.42)$ \\
\hline Etiology (drug regimens) & \\
\hline ASA & $13(28.26 \%)$ \\
\hline Anticoagulants & 11 (23.91\%) \\
\hline Anticoagulant + clopidogrel & $9(19.56 \%)$ \\
\hline No drug & $13(28.26 \%)$ \\
\hline Application complaints & \\
\hline Abdominal pain & $36(78 \%)$ \\
\hline Abdominal mass & $28(60 \%)$ \\
\hline Ecchymosis & $9(19.5 \%)$ \\
\hline Mean hemoglobin level & $9.83 \mathrm{mg} / \mathrm{dl}$ \\
\hline Mean platelet level & 250.954 \\
\hline Mean INR & 2.09 \\
\hline BT findings & \\
\hline Mean size (cm) (SD) & $8.30(4.04)$ \\
\hline Vascular extravasation & $9(19.5 \%)$ \\
\hline Type 1 & $15(32.60 \%)$ \\
\hline Type 2 & $21(45.65 \%)$ \\
\hline Type 3 & $10(21.73 \%)$ \\
\hline Mean RBC transfusion needed & $1.84 \mathrm{U}$ \\
\hline RBC transfusion & $21(45.65 \%)$ \\
\hline Mean FFP need & $2.02 \mathrm{U}$ \\
\hline FFP transfusion & $22(47.82 \%)$ \\
\hline Vascular embolization & $9(19.5 \%)$ \\
\hline Surgery & $2(4.34 \%)$ \\
\hline Morbidity & $6(13.4 \%)$ \\
\hline Abscess & $4(8.69 \%)$ \\
\hline Disseminated intravascular coagulation & $1(2.17 \%)$ \\
\hline Cardiopulmonary complications & $1(2.17 \%)$ \\
\hline Mortality & $2(4.34 \%)$ \\
\hline Mean length of hospital stay (days) (SD) & $5.21(4.69)$ \\
\hline
\end{tabular}

blood transfusion were low mean hemoglobin values, FFP replacement, large mean hematoma size, type $3 \mathrm{RSH}$ on CT, and contrast extravasation $(p=0.001, p=0.003, p=0.001, p$ $=0.001, p=0.001$, and $p=0.023$, respectively). Additionally, more vascular embolization and longer hospital stay were statistically significant in patients who needed more blood transfusion ( $p=0.009$ and $p=0.001$, respectively) (Table 3 ).

\section{Factors Affecting Intervention}

During the follow-up period, nine (19.5\%) patients required intervention. Vascular embolization was performed in eight (17.3\%) of these patients. Surgical intervention was performed in two patients. One patient who had undergone surgery had a history of vascular embolization. The vascular embolization success rate was $87.5 \%$ (7/8). The patient who had undergone surgery after vascular embolization developed mortality due to DIC on the $32^{\text {nd }}$ postoperative day. This patient had 20 ERT and 20 TDP suspension replacements. Only vascular embolization was performed in the other patient who died. This patient was 93 years old and had multiple comorbidities. There was no decrease in hemogram after vascular embolization. Due to cardiopulmonary complications, the patient died on the eighth day of follow-up in the intensive care unit. The factors that statistically increased the risk of intervention were low mean hemoglobin and platelet values, a high need for blood transfusion, contrast extravasation on CT, type 3 hematoma, and long hospital stay $(p=0.045, p=0.011, p=0.007, p=$ $0.0001, p=0.003$, and $p=0.001$, respectively) (Table 4).

\section{DISCUSSION}

The incidence of RSH is approximately $0.0001 \%$ among all emergency department admissions ${ }^{\left({ }^{9}\right)}$. The disease is mostly observed in elderly females with multiple comorbidities $(1,4,6,10)$. In line with the literature, $73 \%(34 / 46)$ of the patients were female in the present patient series, and 31 patients had at least one comorbid disease. The patients were generally of advanced age (mean age $=65.17$ years). Due to RSH, patients were generally admitted to the emergency department with abdominal pain and sometimes with a mass that did not cross the midline due to the enlargement of the hematoma. Ecchymosis may also be observed among the clinical findings ${ }^{(1,11,12)}$. The most common cause of admission to the emergency department for patients in this study was abdominal pain. Of the patients, $78 \%$ (36) had abdominal pain, 60\% (28) had a mass, and 19.5\% (9) had ecchymosis.

The use of anticoagulants is the most common risk factor in the etiology of RSH (1). Antiplatelet use, trauma, pregnancy, 
surgical intervention, difficult exercises, cough attacks, and vascular diseases, such as constipation-related strain, atherosclerosis, and hypertension, are other risk factors effective in the development of RSH ${ }^{(12-16)}$. In the present study, the use of anticoagulants was observed in 20 (43.47\%) patients and was determined as the most common risk factor for RSH. A total of 13 (28.26\%) patients were using ASA, and $9(19.56 \%)$ patients were using clopidogrel. In the case of the patients without drug use anamnesis, three patients had performed heavy lifting activities, two patients had performed difficult exercises, one patient had breast cancer, and one patient had hematological disease anamnesis. No etiological factors were found in six patients. The disease might have been caused by excessive strain due to RSH cough attacks and/or constipation in these patients.
In the literature, there is no detailed study comparing drug regimens during $\mathrm{RSH}$ cases. In the study by Smithson et al. (10), anticoagulant drug subtypes were compared between patients treated conservatively and patients who underwent surgery, and the need for more intervention was found to be statistically significant in patients using low-molecular weight heparin. They thought this was due to the absence of an antidote to this drug ${ }^{(10)}$. In the study by Warren et al. ${ }^{(8)}$, drug regimens were compared in terms of blood transfusion and interventional radiology, and while there was no statistically significant difference between the patients in terms of the need for blood transfusion, patients using ASA were found to have a lower need for interventional radiology. In the comparison between drug regimens in this study, the need for more blood transfusions, larger hematoma

\section{Table 2. Etiology and comparison of the drug regimens that cause rectus sheath hematoma}

\begin{tabular}{|c|c|c|c|c|c|}
\hline & $\begin{array}{l}\text { Group 1 } \\
\text { (only ASA) } \\
\text { ( } n=13 \text { ) }\end{array}$ & $\begin{array}{l}\text { Group } 2 \text { (only } \\
\text { anticoagulant) } \\
(\mathrm{n}=11)\end{array}$ & $\begin{array}{l}\text { Group } 3 \\
\text { (anticoagulant } \\
+ \text { clopidogrel) } \\
(\mathrm{n}=9)\end{array}$ & $\begin{array}{l}\text { Group } 4 \\
\text { (no drug) } \\
\text { (n=13) }\end{array}$ & p-value \\
\hline Mean age (SD) & $72.00(15.26)$ & $73.54(14.00)$ & $66.60(10.80)$ & $50.23(15.10)$ & 0.002 \\
\hline $\begin{array}{l}\text { Gender } \\
\text { Male } \\
\text { Female }\end{array}$ & $\begin{array}{l}3(6.52 \%) \\
10(21.73 \%)\end{array}$ & $\begin{array}{l}1(2.17 \%) \\
10(21.73 \%)\end{array}$ & $\begin{array}{l}4(8.69 \%) \\
5(10.86 \%)\end{array}$ & $\begin{array}{l}4 \text { (8.69\%) } \\
9 \text { (19.56\%) }\end{array}$ & 0.303 \\
\hline Mean CCI (SD) & $6.23(2.12)$ & $5.09(1.51)$ & $5.00(0.70)$ & 1.84 (1.99) & 0.001 \\
\hline Mean BMI $\left(\mathrm{kg} / \mathrm{m}^{2}\right)(\mathrm{SD})$ & $25.61(7.75)$ & $26.90(3.14)$ & $26.11(3.28)$ & $28.92(3.04)$ & 0.060 \\
\hline Mean hemoglobin level (SD) & $9.15(1.80)$ & $9.47(1.02)$ & $8.38(1.70)$ & $11.83(2.23)$ & 0.003 \\
\hline Mean platelet level (SD) & 259.38 (155.21) & $276.00(55.66)$ & $252.22(79.90)$ & $220.38(94.70)$ & 0.321 \\
\hline Mean INR level (SD) & $1.19(0.18)$ & $3.63(2.95)$ & $3.03(1.30)$ & $1.05(0.09)$ & 0.001 \\
\hline Mean RBC transfusion (SD) & $3.61(5.60)$ & $1.81(2.78)$ & $1.77(1.92)$ & $0.15(0.55)$ & 0.002 \\
\hline Per person RBC transfusion & $10(76.92 \%)$ & $5(45.45 \%)$ & $5(55.5 \%)$ & $1(7.8 \%)$ & 0.011 \\
\hline Mean FFP transfusion (SD) & $2.92(5.86)$ & $2.36(2.50)$ & $3(1.32)$ & $0.15(0.55)$ & 0.001 \\
\hline Per person FFP transfusion & $5(38.46 \%)$ & $7(63.63 \%)$ & $9(100 \%)$ & $1(4.54 \%)$ & 0.001 \\
\hline Size of hematoma (SD) & $10.07(4.19)$ & $9.72(3.90)$ & 7.66 (3.74) & $5.76(3.03)$ & 0.016 \\
\hline $\begin{array}{l}\text { Hematoma types } \\
\text { Type } 1 \\
\text { Type } 2 \\
\text { Type } 3\end{array}$ & $\begin{array}{l}2(4.34 \%) \\
6(13.04 \%) \\
5(10.86 \%)\end{array}$ & $\begin{array}{l}3(6.52 \%) \\
5(10.86 \%) \\
3(6.52 \%)\end{array}$ & $\begin{array}{l}3(6.52 \%) \\
5(10.86 \%) \\
1(2.17 \%)\end{array}$ & $\begin{array}{l}7(15.21 \%) \\
5(10.86 \%) \\
1(2.17 \%) \\
\end{array}$ & 0.078 \\
\hline Vascular extravasation & $3(23.07 \%)$ & $3(27.27 \%)$ & 1(11.11\%) & $2(15.38 \%)$ & 0.777 \\
\hline Vascular embolization & $3(23.07 \%)$ & $2(18.18 \%)$ & $1(11.11 \%)$ & $2(15.38 \%)$ & 0.899 \\
\hline Surgery & $2(15.38 \%)$ & 0 & 0 & 0 & 0.152 \\
\hline Total intervention & $4(30.76 \%)$ & $2(18.18 \%)$ & l(11.11\%) & $2(15.38 \%)$ & 0.669 \\
\hline Length of hospital stay (days) (SD) & $7.53(7.80)$ & 5.09 (1.92) & $4.66(1.41)$ & $3.38(2.72)$ & 0.004 \\
\hline Morbidity & $4(30.76 \%)$ & $1(9.09 \%)$ & l(11.11\%) & 0 & 0.086 \\
\hline Mortality & $2(15.38 \%)$ & 0 & 0 & 0 & 0.152 \\
\hline
\end{tabular}


sizes, and longer hospital stay were found to be statistically significant in the patients using ASA. ASA irreversibly inhibits the cyclooxygenase (COX) pathway in platelets as an irreversible non-selective COX-inhibitor, preventing the formation of thromboxane-A2 and platelet aggregation, and this inhibition lasts for approximately 7 days of the platelet life. It has no other antidote (17). Anticoagulants have an antidote called protamine sulfate, and vitamin K, FFP, and prothrombin complex concentrates may be used in case of an overdose. Vitamin K-dependent clotting factors allow de novo synthesis, whereas FFP and prothrombin complex concentrates provide complementary clotting factors, including $\mathrm{C}$ and $\mathrm{S}$ proteins in some preparations, and INR begins to decrease within $1-2$ hours ${ }^{(18,19)}$. In the study by

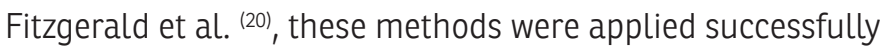
to reverse the anticoagulant effect. The fact that we have more agents to eliminate the anticoagulant effect causes the bleeding to stop earlier, and the need for blood is less in these patients, which is in contrast to patients who used ASA since no agent eliminates the effect of ASA and its duration of action continues for 7 days despite discontinuation of the drug. This might have caused more need for blood transfusion, larger hematoma sizes, and longer hospital stay. There was no significant difference between drug groups in terms of interventional procedures and the need for surgery. In the non-drug group, the mean age and $\mathrm{CCl}$ were significantly lower. The group that had the least need for enzyme replacement therapy was the non-drug group. In the literature, patients with RSH who did not use drugs were younger, which is compatible with the results of the present study ${ }^{(1,3)}$. Comparable data on mortality and morbidity due to RSH caused by different drug regimens could not be found

\section{Table 3. Factors affecting blood transfusion}

\begin{tabular}{|c|c|c|c|}
\hline & $\begin{array}{l}\text { RBC transfusion }(+) \\
(n=21)\end{array}$ & $\begin{array}{l}\text { RBC transfusion (-) } \\
(\mathrm{n}=25)\end{array}$ & $\mathrm{p}$-value \\
\hline Mean age (SD) & $72.52(14.40)$ & $59.00(16.44)$ & 0.005 \\
\hline \multicolumn{4}{|l|}{ Gender } \\
\hline Male & 4 (19.04\%) & $8(32 \%)$ & 0.319 \\
\hline Female & $17(80.96 \%)$ & $17(68 \%)$ & \\
\hline Mean BMI $\left(\mathrm{kg} / \mathrm{m}^{2}\right)(\mathrm{SD})$ & $26.04(2.71)$ & $27.72(3.54)$ & 0.119 \\
\hline Mean CCI (SD) & $6.28(1.38)$ & $2.96(2.05)$ & 0.001 \\
\hline \multicolumn{4}{|l|}{ Drug regimens } \\
\hline ASA & $10(47.61 \%)$ & $3(12 \%)$ & \\
\hline Anticoagulant & $5(23.80 \%)$ & $6(24 \%)$ & 0.002 \\
\hline Anticoagulant + clopidogrel & $5(23.80 \%)$ & $4(16 \%)$ & \\
\hline No drug & $1(4.76 \%)$ & $12(48 \%)$ & \\
\hline Mean hemoglobin levels (SD) & $8.34(1.47)$ & $11.09(1.84)$ & 0.001 \\
\hline Mean platelet levels (SD) & 257.95 (140.09) & $245.04(65.93)$ & 0.834 \\
\hline Mean INR Levels (SD) & $1.87(1.35)$ & $2.28(2.25)$ & 0.447 \\
\hline FFP transfusion & $14(66.66 \%)$ & $7(28 \%)$ & 0.003 \\
\hline \multicolumn{4}{|l|}{ Hematoma types } \\
\hline Type 1 & $4(19.04 \%)$ & $11(44 \%)$ & 0.001 \\
\hline Type 2 & $8(38.09 \%)$ & $13(52 \%)$ & \\
\hline Type 3 & $9(42.85 \%)$ & $1(4 \%)$ & \\
\hline Vascular extravasation & $7(33.33 \%)$ & $2(8 \%)$ & 0.023 \\
\hline Size of hematoma (cm) (SD) & $10.47(3.66)$ & $6.48(3.44)$ & 0.001 \\
\hline Vascular embolization & 7 (33.33\%) & $1(4 \%)$ & 0.009 \\
\hline Surgery & $2(9.52 \%)$ & 0 & 0.203 \\
\hline Total intervention & 8 (38.09\%) & $1(4 \%)$ & 0.007 \\
\hline Length of hospital stay (days) (SD) & $7.42(6.20)$ & 3.36 (1.13) & 0.001 \\
\hline
\end{tabular}


in the literature. In this study, the rates of mortality and morbidity were similar between the drug regimens.

Abdominal ultrasonography (USG) and computerized tomography are quite effective imaging methods for diagnosing RSH. The sensitivity of USG in the diagnosis of RSH is between $80 \%$ and $90 \%$. Tomography is the best diagnostic imaging method, and its sensitivity and specificity values are $100 \%{ }^{(16,21,22)}$. In this study, 34 patients underwent USG, and 28 (82.3\%) patients were diagnosed by this method. Tomography was performed in 43 patients, and all patients (100\%) could be diagnosed with RSH. The results of the present study were found to be compatible with the literature.

Regarding treatment, the severity of the RSH is important, and bed resting and analgesic treatment may be sufficient in clinically stable patients ${ }^{(3)}$. In large hematomas, fluid resuscitation and blood transfusion may be performed in hemodynamically unstable patients, and it is also recommended that anticoagulants and antiplatelets are discontinued ${ }^{(3,8)}$. Vascular embolization or surgical treatment options should be considered in cases where conservative treatment is unsuccessful ${ }^{(3,10)}$. Surgical treatment should not be chosen as the first option because draining the hematoma eliminates the tamponade effect and may cause more bleeding ${ }^{(23)}$. Vascular embolization should be the first treatment of choice in patients who do not respond to conservative treatment ${ }^{(23,24)}$. In this study, 37 (80.4\%) patients were treated conservatively. Their anticoagulants and antiplatelets were cut. Fluid resuscitation and, if needed, blood transfusion in those who used anticoagulants, FFP replacement, and vitamin $\mathrm{K}$ were applied. When INR dropped below 2.5 in patients using anticoagulants, lowmolecular weight heparin was initiated if the patients were hemodynamically stable. In the study by Sheth et al. (3), $80 \%$ of patients were treated conservatively, which is in accordance with the current results. In the study by Cherry

\section{Table 4. Factors affecting the intervention}

\begin{tabular}{|c|c|c|c|}
\hline & $\begin{array}{l}\text { Intervention (+) (n } \\
=9 \text { ) }\end{array}$ & $\begin{array}{l}\text { Intervention (-) (n } \\
=37 \text { ) }\end{array}$ & $\mathrm{p}$-value \\
\hline Mean age (SD) & $65.11(19.24)$ & $65.18(16.47)$ & 0.870 \\
\hline \multicolumn{4}{|l|}{ Gender } \\
\hline Male & $2(22.22 \%)$ & $10(27.02 \%)$ & 0.765 \\
\hline Female & 7 (77.77\%) & $27(72.97 \%)$ & \\
\hline Mean BMI (SD) & $26.55(2.40)$ & $27.05(3.46)$ & 0.828 \\
\hline Mean CCI (SD) & $5.33(2.23)$ & $4.22(2.45)$ & 0.169 \\
\hline \multicolumn{4}{|l|}{ Drug regimens } \\
\hline ASA & $4(44.44 \%)$ & $9(24.32 \%)$ & \\
\hline Anticoagulant & $2(22.22 \%)$ & $9(24.32 \%)$ & 0.669 \\
\hline Anticoagulant + clopidogrel & $1(11.11 \%)$ & $8(21.62 \%)$ & \\
\hline No drug & $2(22.22 \%)$ & $11(29.72 \%)$ & \\
\hline Mean hemoglobin level (SD) & $8.55(2.05)$ & $10.15(2.09)$ & 0.045 \\
\hline Mean platelet level (SD) & $175(98.87)$ & $269.40(99.45)$ & 0.011 \\
\hline Mean INR (SD) & $1.72(1.64)$ & 2.19 (1.95) & 0.567 \\
\hline Mean RBC transfusion (SD) & $6.55(5.85)$ & $0.70(1.102)$ & 0.007 \\
\hline Per person RBC transfusion & $8(88.88 \%)$ & $13(35.13 \%)$ & 0.001 \\
\hline Per person FFP transfusion & $7(77.77 \%)$ & $15(40.54 \%)$ & 0.003 \\
\hline Vascular extravasation & $8(88.88 \%)$ & $1(2.70 \%)$ & 0.0001 \\
\hline Size of hematoma (SD) & $9.22(2.04)$ & $8.08(4.38)$ & 0.217 \\
\hline \multicolumn{4}{|l|}{ Hematoma types } \\
\hline Type 1 & $0(0 \%)$ & $15(40.5 \%)$ & 0003 \\
\hline Type 2 & $3(33.33 \%)$ & $18(48.64 \%)$ & 0.003 \\
\hline Type 3 & $6(66.66 \%)$ & $4(10.81 \%)$ & \\
\hline Mean Length of hospital stay (day) (SD) & $10.00(8.94)$ & $4.05(1.61)$ & 0.001 \\
\hline
\end{tabular}


et al. (1), however, 92\% of patients were successfully treated conservatively only by observation or medically.

When conservative treatment is unsuccessful, the first-line treatment is vascular embolization, and success rates have been reported to be between $70 \%$ and $98 \%{ }^{(1,25-28)}$. In the present study, vascular embolization was successful in 7 of 8 patients $(87.5 \%)$, which is consistent with the literature. Open surgery was performed in two patients. Blood transfusions to the patients were reported at various rates in the literature. In the study by Warren et al. ${ }^{(8)}, 80 \%$ of patients had blood transfusions. In the study by Smithson et al. ${ }^{(10)}$, blood transfusion was needed at a rate of $50 \%$. In another study, blood transfusions were reported at a rate of $39 \%{ }^{(1)}$. In the present study, blood transfusion was performed in $45 \%$ of the patients. In the study by Warren et al. ${ }^{(8)}$, the only statistically significant predictive factor for blood transfusion was "shock." No statistically significant difference was found in comparisons made among drug regimens, age, and comorbidities. In the study by Smithson et al. ${ }^{(10)}$, statistically more blood transfusions were performed in patients requiring intervention. In the study by Karapolat et al. ${ }^{(29)}$, a comparison was made in terms of blood transfusion according to hematoma types in tomography, and it was seen that the need for blood transfusion was similar in all types. In the present study, contrary to the literature, it was found that blood transfusion was statistically significant in older patients with high $\mathrm{CCl}$ values, patients using only ASA, patients with contrast extravasation on $\mathrm{CT}$, patients with wider and type 3 hematoma, and patients requiring intervention. In the study by Cherry et al. (1), an average of $3.5 \mathrm{U}$ of erythrocyte suspension replacement was reported in patients requiring blood transfusion. In the present study, an average of $4 \mathrm{U}$ of erythrocyte suspension replacement was performed in patients requiring blood transfusion.

Risk factors for intervention have been reported in a small number of studies ${ }^{(8,10)}$. In the study by Warren et al. (8), the need for intervention was less in the group using ASA, whereas factors such as age, comorbid diseases, and blood transfusion requirement did not increase the need for intervention. Smithson et al. ${ }^{(10)}$ found that the need for intervention was higher in patients using low-molecular weight heparin, patients with the clinical picture of shock, patients who underwent blood transfusion, and patients with longer hospital stay. In the study by Baekgaard et al. (30), the risk factors for intervention were extravasation on CT and pain in the flank area. In the present study, low mean hemoglobin and platelet levels, blood transfusion, contrast extravasation, type 3 hematoma, and long hospital stay were statistically significant risk factors for intervention.

The mean length of hospital stay has been reported in the literature at intervals ranging from 8 to 25 days ${ }^{(10,20,29)}$. In this study, the mean length of hospital stay was less than that in the literature at 5.2 days. Factors prolonging the mean length of the hospital stay were ASA use, blood transfusion, and intervention.

Mortality is rarely seen in RSH cases, and several cases have been reported in studies till date ${ }^{(1,10)}$. In the study by Sheth et al. ${ }^{(3)}$, the mortality rate was reported as $0 \%$. In the study by Warren et al. ${ }^{(8)}, 13$ patients died, but none were reported to die due to the bleeding. In the case series by Fitzgerald et al. ${ }^{(20)}$ comprising 7 patients, mortality was reported in a patient using ASA. A total of two patients died in the present study. These two patients were in the group using ASA only. Despite surgery and vascular embolization, bleeding could not be brought under control in one patient, and mortality developed due to the DIC, clinical picture due to excessive blood transfusion. In the other patient, mortality due to cardiopulmonary complications developed due to comorbidities.

\section{CONCLUSION}

In conclusion, the comparison of drug regimens revealed that hematoma size was wider, more blood transfusions were needed, and the length of hospital stay were longer in patients who used ASA and that these patients had a worse prognosis than patients who were using other drug regimens. Only ASA use, low hemoglobin levels, long hospital stay, contrast extravasation, and type 3 hematoma on CT were associated with more blood transfusion and intervention. Larger multicenter studies are needed to identify risk factors affecting the prognosis of RSHs and to be an effective guide in their treatment.

\section{Ethics}

Ethics Committee Approval: Ethical approval from the local ethics committee (2020-299/06.07.2020) was obtained.

Informed Consent: Is a retrospective study.

Peer-review: Externally peer reviewed.

\section{Authorship Contributions}

Concept: A.S., M.A.B., B.A., T.D., E.G., S.F., H.A., A.K., M.K., Design: A.S., M.A.B., B.A., T.D., E.G., S.F., H.A., A.K., M.K., Writing: A.S., M.A.B., B.A., T.D., E.G., S.F., H.A., A.K., M.K. 
Conflict of Interest: No conflict of interest was declared by the authors.

Financial Disclosure: The authors declared that this study received no financial support.

\section{REFERENCES}

1. Cherry WB, Mueller PS. Rectus sheath hematoma: review of 126 cases at a single institution. Medicine (Baltimore). 2006 Mar;85:105-10. doi: 10.1097/01.md.0000216818.13067.5a.

2. Hatjipetrou A, Anyfantakis D, Kastanakis M. Rectus sheath hematoma: a review of the literature. Int J Surg. 2015;13:267-71. doi: 10.1016/j. ijsu.2014.12.015.

3. Sheth HS, Kumar R, DiNella J, Janov C, Kaldas H, Smith RE. Evaluation of risk factors for rectus sheath hematoma. Clin Appl Thromb Hemost. 2016;22:292-6. doi: 10.1177/1076029614553024.

4. Núñez Fernández MJ, García Blanco A, García García JC, Castro Paredes B, López Soto A, Bon AB. Hematoma del recto anterior del abdomen: experiencia en un hospital comarcal [Hematoma of the rectus abdominis. experience of a primary care hospital]. Rev Clin Esp. 2011;211:85-9. (Spanish) doi: 10.1016/j.rce.2010.07.011.

5. Girolami A, Allemand E, Tezza F, Pellati D, Scandellari R. Rectus muscle sheath haematoma in a patient with congenital FX deficiency and in another with congenital FVII deficiency. Haemophilia. 2010;16:182-5. doi: 10.1111/j.1365-2516.2009.02091.x.

6. Berná JD, Zuazu I, Madrigal M, García-Medina V, Fernández C, Guirado F. Conservative treatment of large rectus sheath hematoma in patients undergoing anticoagulant therapy. Abdom Imaging. 2000;25:230-4. doi: $10.1007 / 5002610000007$.

7. Carrascosa MF, Delgado-Tapia MA, Casuso-Sáenz E, Cano-Hoz M. Spontaneous rectus sheath haematoma. Lancet Gastroenterol Hepatol. 2017;2:538. doi: 10.1016/S2468-1253(17)30149-8.

8. Warren $\mathbf{M H}$, Bhattacharya $B$, Maung AA, Davis KA. Contemporary management of spontaneous retroperitoneal and rectus sheath hematomas. Am J Surg. 2020;219:707-10. doi: 10.1016/j. amjsurg.2019.05.002.

9. Garcia Bear I, Macias Robles MD, Baldonedo Cernuda RF, Alvarez Perez JA. Spontaneous hematoma of the sheath of the rectus abdominis muscle: a challenge for the diagnosis. Emergencias 2000;12:269-71. Kaynağa ulaşılamadı

10. Smithson A, Ruiz J, Perello R, Valverde M, Ramos J, Garzo L. Diagnostic and management of spontaneous rectus sheath hematoma. Eur J Intern Med. 2013;24:579-82. doi: 10.1016/j.ejim.2013.02.016.

11. Sahin M, Coskun S, Cobanoglu M, Kilicaslan I, Atalar E. Rapidly onset rectus sheath hematoma mimicking cholecystitis. Am J Emerg Med. 2011;29:698.e5-8. doi: 10.1016/j.ajem.2010.08.003

12. Kasotakis G. Retroperitoneal and rectus sheath hematomas. Surg Clin North Am. 2014;94:71-6. doi: 10.1016/j.suc.2013.10.007.

13. Tolcher MC, Nitsche JF, Arendt KW, Rose $\mathrm{CH}$. Spontaneous rectus sheath hematoma pregnancy: case report and review of the literature. Obstet Gynecol Surv. 2010;65:517-22. doi: 10.1097/0GX.0b013e3181f87eaf.

14. Maharaj D, Ramdass M, Teelucksingh S, Perry A, Naraynsingh V. Rectus sheath haematoma: a new set of diagnostic features. Postgrad Med J. 2002;78:755-6. doi: 10.1136/pmj.78.926.755.
15. Linhares M, Lopes Filho GJ, Bruna PC, Ricca AB, Sato NY, Sacalabrini M. Spontaneous hematoma of the rectus abdominis sheath: a review of 177 cases with report of 7 personal cases. Int Surg. 1999;84:251-7.

16. Zainea $G G$, Jordan $F$, Rectus sheath hematomas: their pathogenesis, diagnosis, and management, Am. Surg. 1988;54:630-3.

17. Björklund L, Wallander MA, Johansson S, Lesén E. Aspirin in cardiology-benefits and risks. Int J Clin Pract. 2009;63:468-77. doi: 10.1111/j.17421241.2008.01908.x.

18. Britt RB, Brown JN. Characterizing the severe reactions of parenteral vitamin Kl. Clin Appl Thromb Hemost. 2018;24:5-12. doi: 10.1177/1076029616674825.

19. Kaide CG, Thompson LR. Transfusion therapy: blood and blood products. Roberts And Hedges' Clinical Procedures in Emergency Medicine. 2010;17(6), 358 kaynağa ulașılamadı

20. Fitzgerald JE, Fitzgerald LA, Anderson FE, Acheson AG. The changing nature of rectus sheath haematoma: case series and literature review. Int J Surg. 2009;7:150-4. doi: 10.1016/j.ijsu.2009.01.007.

21. Fukuda T, Sakamoto I, Kohzaki S, et al. Spontaneous rectus sheath hematomas: clinical and radiological features. Abdom Imaging. 1996;21:58-61. doi: 10.1007/s002619900010.

22. Salemis NS, Gourgiotis S, Karalis G. Diagnostic evaluation and management of patients with rectus sheath hematoma. A retrospective study. Int J Surg. 2010;8:290-3. doi: 10.1016/j.ijsu.2010.02.011.

23. Donaldson J, Knowles CH, Clark SK, Renfrew I, Lobo MD. Rectus sheath haematoma associated with low molecular weight heparin: a case series. Ann R Coll Surg Engl. 2007;89:309-12. doi: 10.1308/003588407X179152.

24. Perello R, Smithson A, Miret $C$, Nolla M. Radiología intervencionista en el tratamiento del hematoma de pared abdominal. Med Cin (Barc). 2005;125:77-8. doi:10.1157/13076468

25. Farrelly C, Fidelman N, Durack JC, Hagiwara E, Kerlan RK Jr. Transcatheter arterial embolization of spontaneous life-threatening extraperitoneal hemorrhage. J Vasc Interv Radiol. 2011;22:1396-402. doi: 10.1016/j.jvir.2011.06.008.

26. Maleux G, Van Sonhoven F, Hofkens PJ, et al. Soft tissue bleeding associated with antithrombotic treatment: technical and clinical outcomes after transcatheter embolization. J Vasc Interv Radiol. 2012;23:910-916.el. doi: 10.1016/j.jvir.2012.04.005.

27. Dohan A, Sapoval M, Chousterman BG, di Primio M, Guerot E, Pellerin O. Spontaneous soft-tissue hemorrhage in anticoagulated patients: safety and efficacy of embolization. AJR Am J Roentgenol. 2015;204:1303-10. doi: 10.2214/AJR.14.12578.

28. Ozyer U. Transcatheter arterial embolization with n-butyl-2cyanoacrylate in the management of spontaneous hematomas. Cardiovasc Intervent Radiol. 2017;40:41-9. doi: 10.1007/s00270-0161463-6.

29. Karapolat B, Tasdelen HA, Korkmaz HAA. Conservative treatment of spontaneous rectus sheath hematomas: single center experience and literature review. Emerg Med Int. 2019;2019:2406873. doi: 10.1155/2019/2406873.

30. Baekgaard JS, Eskesen TG, Lee JM, et al. Spontaneous retroperitoneal and rectus sheath hemorrhage-management, risk factors and outcomes. World J Surg. 2019;43:1890-7. 